\title{
Analysis of Soil Characteristics Near the Solid Waste Landfill Site
}

\author{
P. Vijayalakshmi†, P. K. Raji, P. Eshanthini, R. Rahul Vijay Bennet and Rajesh Ravi \\ Department of Civil Engineering, Sathyabama Institute of Science and Technology, Chennai, Tamilnadu, India \\ †Corresponding author: P. Vijayalakshmi; vijayalakshmipanneerselvam@yahoo.co.in
}

Nat. Env. \& Poll. Tech.

Website: www.neptjournal.com

Received: 06-09-2019

Revised: $30-09-2019$

Accepted: 11-12-2019

Key Words:

Dumpsite

Leachate

Soil pollution

Solid waste management

\begin{abstract}
In this project, the study of soil characteristics due to the municipal solid waste was carried out in a selected location around the recently closed Municipal Solid Waste (MSW) dumpsite located opposite to Periya Eri in Chromepet, Chennai. Soil samples were collected from the selected location, i.e. 2 sites within $1500 \mathrm{~m}$ from the dumpsite and another 2 sites beyond $1500 \mathrm{~m}$ from the dump yard. Total 12 soil samples from 4 sites were collected from a ground depth of $0-30 \mathrm{~cm}, 30-60 \mathrm{~cm}$ and $60-90 \mathrm{~cm}$ below the surface. The collected soil samples have been analyzed for $\mathrm{pH}$, moisture, total organic matter, ash content, total organic carbon, specific gravity, conductivity and bulk density and the result were compared with the standards. The study suggested, providing Permeable Reactive Barriers (PRBs) around the solid waste dump site/landfill for reducing the leachate concentration before entering to the soil and thus soil contamination can be minimized to some extent and this technology is costeffective and eco-friendly since the materials used in the barriers are locally available and low-cost which is sustainable and protect human health, nature and the environment. This study indicated that soil properties did not reach high pollution levels, and therefore posed a low eco-risk potential in surface

soil near the landfill.
\end{abstract}

\section{INTRODUCTION}

Soil plays a central role in food safety as it determines the possible composition of food and feed at the root of the food chain. Maintenance or enhancement of soil quality is a more important criterion for analysis and sustainability of soil ecosystems (Schoenholtz 2000)

The soil quality analysis includes an analysis of parameters and processes which affect soil to operate efficiently as a component of a sound ecosystem (Tale \& Ingole 2015). Soil is one of the important natural resources which provides the main mineral elements for plant growth and crop production. Formation of $1 \mathrm{~cm}$ topsoil layer requires 100-400 years (Deshmukh 2012). Systematic depletion of public health and general living conditions of a given populace is largely traceable to the adaptation of man to his less than the wholesome environment. In the past, waste disposal was not taken too seriously in the developing countries, but in recent years with increasing awareness of the environmental hazards caused by wastes, much concern has been directed to its management (Igwe et al. 2002). The increase in population coupled with rural-urban drift has increased the quantity of wastes generated in the urban areas and the developing countries are faced with not only the challenges of collecting the wastes but how and where to dispose of it without causing further environmental hazards (Oguneleka 2009, Oguche 2013). When pollutants or contaminants find their way into the soil, they interact with the soil and thereby change the chemical and physical properties of the soil.

\section{Study Area}

The study area is located around the existing MSW dumpsite (latitude: 12 ${ }^{\circ} 7^{\prime} 21.1134^{\prime \prime} \mathrm{N}$ and longitude: $80^{\circ} 09^{\prime} 0.9678^{\prime \prime}$ E) at an altitude of 55 feet above the mean sea level (Fig. 1). The area is having low humidity and high temperature. During winter, the temperature is around $20^{\circ} \mathrm{C}$ which increases up to a maximum of $44^{\circ} \mathrm{C}$ in summer. The average annual rainfall of this region is about $1200 \mathrm{~mm}$ and forty per cent of the annual rainfall is contributed by the southwest monsoon from June to September. More than $60 \%$ of the annual rainfall from October to December is due to northeast monsoon (Vijayalakshmi \& Marykutty Abraham 2017). The topography of this region gently slopes towards west and east.

\section{Sample Collection and Analysis}

Two sites within $1500 \mathrm{~m}$ around the dumpsite (namely site L1 and site L2) and another 2 sites between $1500 \mathrm{~m}$ and $3000 \mathrm{~m}$ away from the dumpsite (namely site L3 and site L4) have been selected (Fig. 2A). From each site, the soil samples were collected from $0-30 \mathrm{~cm}, 30-60 \mathrm{~cm}$ and $60-90 \mathrm{~cm}$ depth below the ground surface (Fig. 2B). Fig. 3 shows photographs of the collected soil samples. The soil samples were analyzed for physical properties by the methods given in Table 1 . 
A stainless steel trowel was used to collect samples and the soil samples were preserved in polythene bags for further analysis. Soil samples were air-dried for $72 \mathrm{~h}$, crushed, passed through a 2-mm-mesh sieve, and stored at ambient temperature before the soil properties were analyzed (Sharma et al. 2007).

\section{RESULTS AND DISCUSSION}

\section{pH}

The most significant property of soil is its $\mathrm{pH}$ level, which affects all other parameters of soil. If the $\mathrm{pH}$ is less than 6 then it is said to be acidic soil, when the $\mathrm{pH}$ range from 6-8.5 it is a normal soil and when it is greater than 8.5 the soil is said to be alkaline. $\mathrm{pH}$ has been reported as a simple and direct measure of the overall chemical condition of the soil and at pH 6.5, nutrient availability to plants from the soil is at its highest (Praveena \& Rao 2016).
The $\mathrm{pH}$ of the collected soil sample at site 2 (L2) is higher than site 1 (L1), which has been collected within $1500 \mathrm{~m}$ from the dumpsite (Table 2). The value of $\mathrm{pH}$ of collected soil samples reduces with increase in distance from the dumping site. The values of $\mathrm{pH}$ in the soil samples are within the Indian standards.

Fig. 4 clearly shows the variation in $\mathrm{pH}$ at all the site locations and for each layer. The $\mathrm{pH}$ at $\mathrm{L} 2$ is higher than other site locations. From Fig. 4(b), the level of $\mathrm{pH}$ at $\mathrm{L} 1$ is lower than the L2, and then the level of $\mathrm{pH}$ decreases at L3 and L4 as the distance from the dumpsite increases.

\section{Moisture}

Water content or moisture content is the quantity of water contained in a material, such as soil called soil moisture. Absorption of the nutrients by soil largely depends on the moisture content of the soil, which also shows its effect on the texture of the soil.

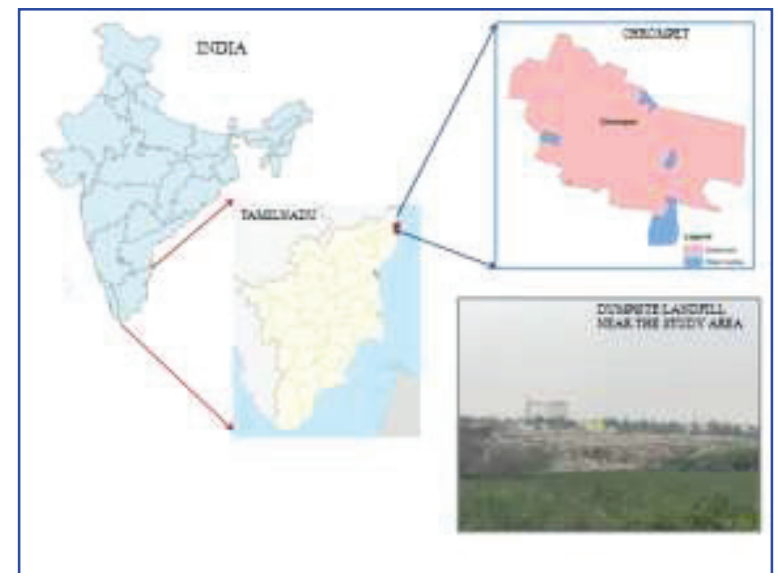

Fig. 1: Location map of the study area.

Table 1: Methods used for the testing of the collected soil sample.

\begin{tabular}{|ll|}
\hline Parameters & Testing Methods \\
\hline $\mathrm{pH}$ & EPA Method-9045 D rev 4,2004 \\
Moisture, \% & FAO Method(Pg: NO:23) 2007 (AIR OVEN METHOD) \\
Total Organic Matter, \% & IS 10158-1968 (RA 2003) \\
Ash Content, $\%$ & IS 1155:1968 (RA 2005) \\
Total Organic Carbon \% & FAO Method (PG NO. 61) 2007 (Walkley Black Wet Combustion Method) \\
Specific Gravity & TNTH/SOP/SOIL/021 \\
Conductivity $(\mu \mathrm{S} / \mathrm{cm})$ & IS 14767:2000 \\
Bulk Density $\left(\mathrm{g} / \mathrm{cm}^{3}\right)$ & FAO Method (PG NO: 35) 2007 \\
Chloride as $\mathrm{Cl}(\mathrm{mg} / \mathrm{kg})$ & FAO Method (PG NO: 48) 2007 (Titrimetric Method) \\
\hline
\end{tabular}




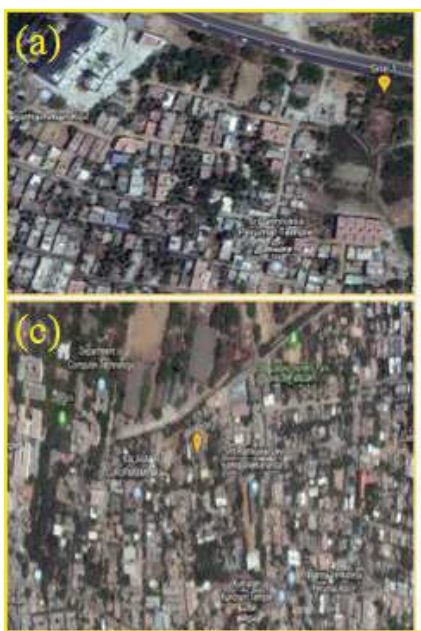

Fig. 2(A): Site selected for collection of samples.
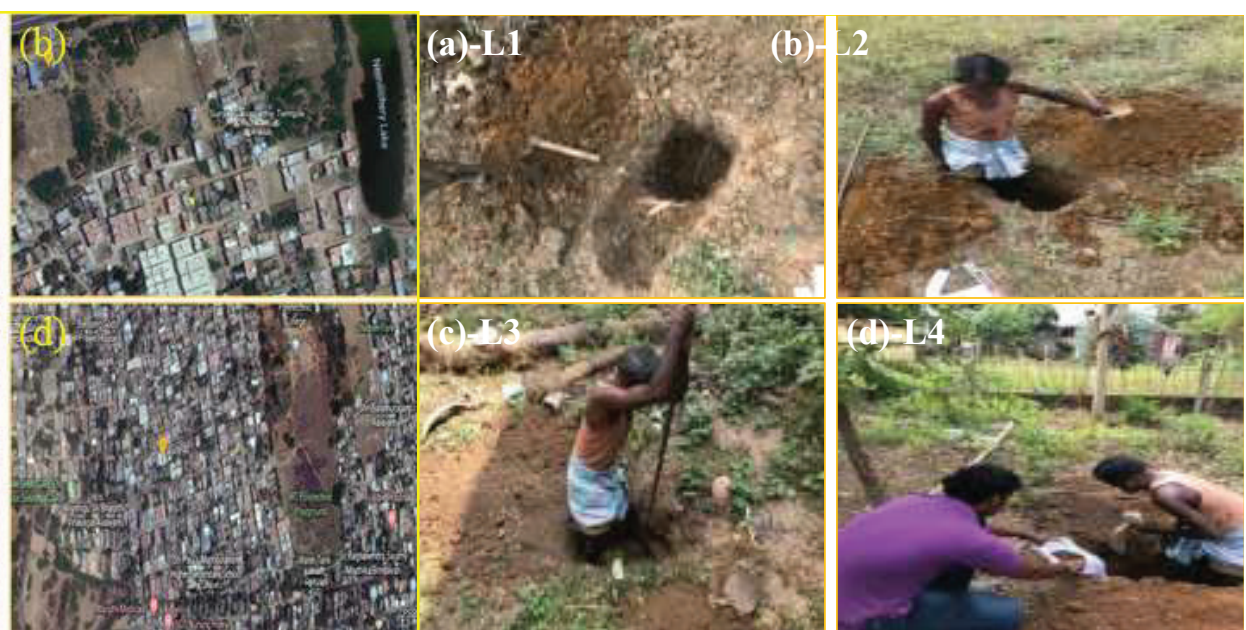

Fig. 2(B): Collection of the samples.
The maximum allowable concentration of moisture in the soil sample should be in a range between $11 \%$ to $17 \%$ and the moisture content in the collected soil samples are within the Indian standards.

Fig. 5 and Table 3 show the variation in moisture at all the site locations and for each layer. The moisture at L1 and L2 is higher than other site locations (L3 and L4). From Fig. 5 (a), the value of moisture at L1 is lower than L2 for $1^{\text {st }}$ and $3^{\text {rd }}$ layer and higher in $2^{\text {nd }}$ layer, then the level of moisture lowers at L3 and L4 the value decrease for $1^{\text {st }}$ layer and increases for $2^{\text {nd }}$ and $3^{\text {rd }}$ layer.

\section{Total Organic Matter}

The high rate of organic matter decomposition under high temperature leads to extremely high oxidizing condition (Uma et al. 2016). Total organic matter (TOM) or soil organic matter (SOM) is the organic matter component of soil, consisting of plant and animal residues at various stages of

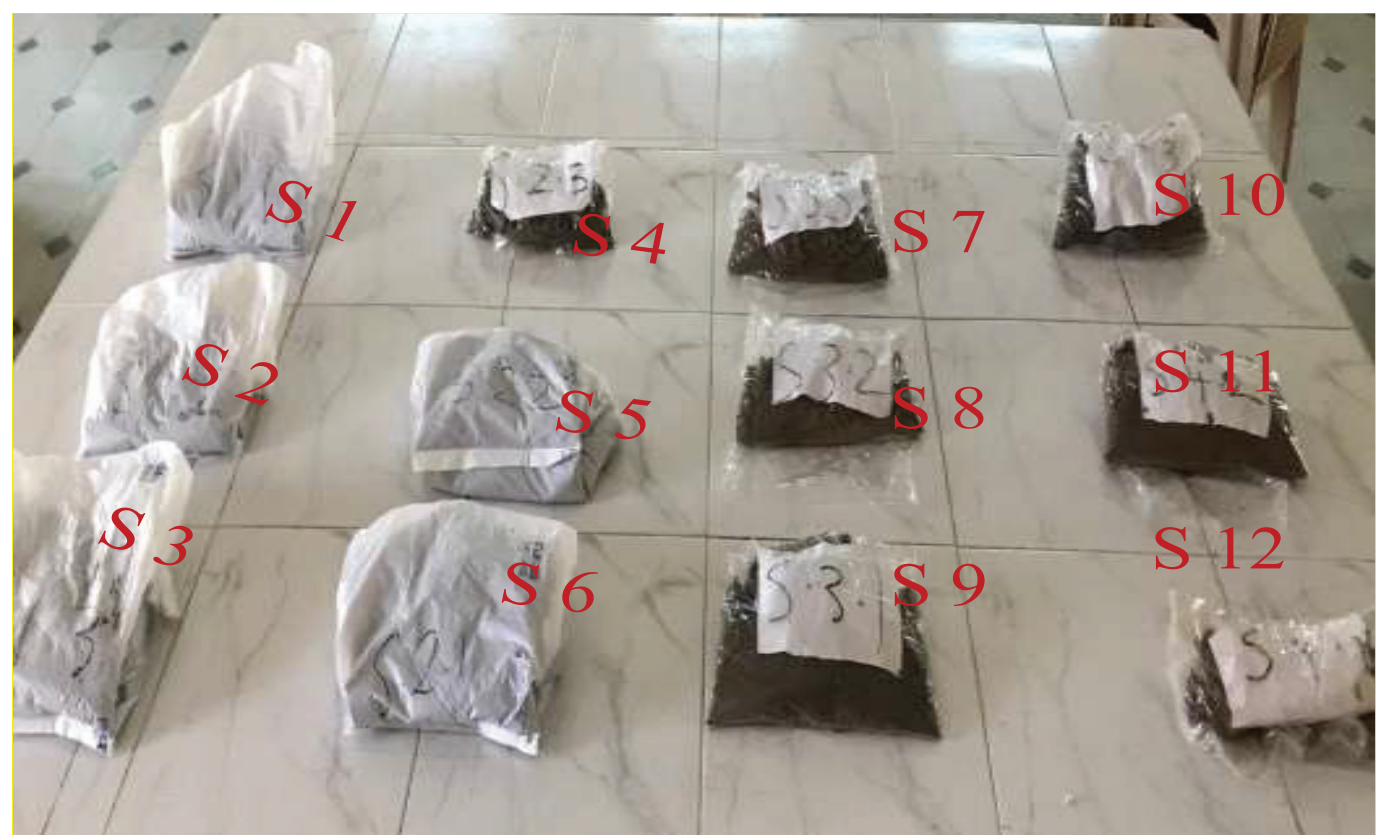

Fig. 3: Collected soil samples. 


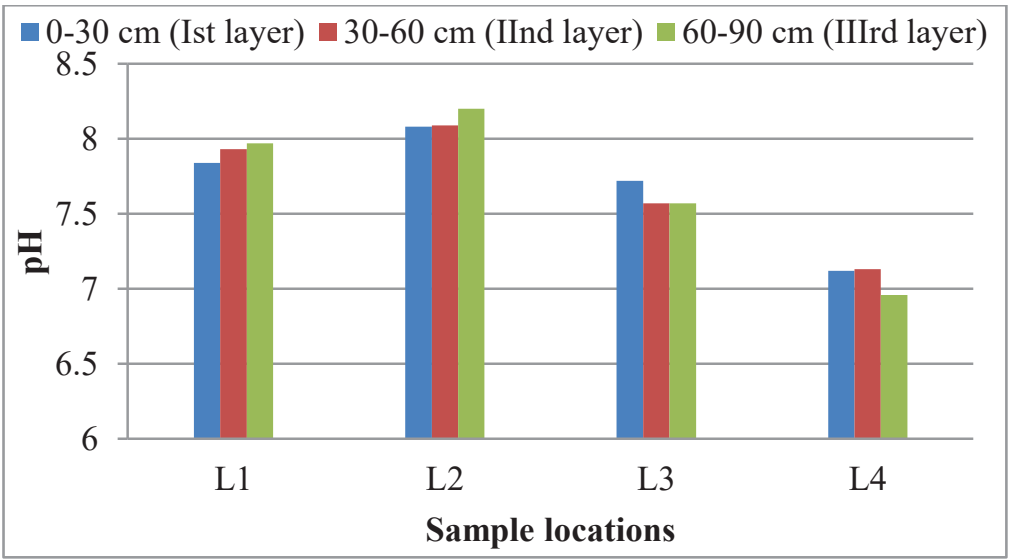

Fig. 4: Variation of $\mathrm{pH}$ of collected soil samples.

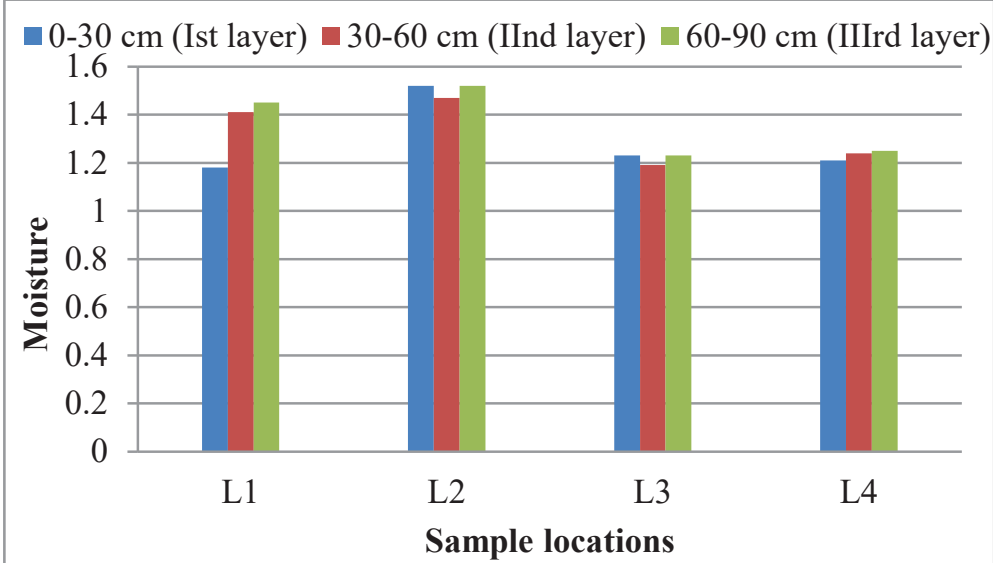

Fig. 5: Variation of moisture content of the collected soil samples.

decomposition, cells and tissues of soil organisms, and substances synthesized by soil organisms. SOM exerts numerous positive effects on soil physical and chemical properties, as well as the soil's capacity to provide regulatory ecosystem services. Particularly, the presence of SOM is regarded as being critical for soil function and soil quality.

Fig. 6 and Table 4 show the variation in total organic matter at all the site locations and for each layer. The total organic matter at L1 and L2 is higher than other site locations.
From Fig. 6(a), $1^{\text {st }}$ layer total organic matter at L1 is higher than L2, the level of total organic matter increases for L3 and then decreases for L4. From Fig. 6(b) and 6(c), $2^{\text {nd }}$ and $3^{\text {rd }}$ layer total organic matter at L1 is equal to L2, then the level of total organic matter decrease at L3 and increases L4 for the $2^{\text {nd }}$ layer.

\section{Ash Content}

The substance remaining after ignition is the ash. The ash

Table 2: Value of $\mathrm{pH}$ at various depths of soil below the ground surface.

\begin{tabular}{|c|c|c|c|c|}
\hline Soil Sample Location & $\mathrm{I}^{\text {st }}$ layer $0-30 \mathrm{~cm}$ & II $^{\text {nd }}$ layer $30-60 \mathrm{~cm}$ & III $^{\text {rd }}$ layer $60-90 \mathrm{~cm}$ & Maximum Allowable value \\
\hline L1 & 7.84 & 7.93 & 7.97 & \\
\hline $\mathrm{L} 2$ & 8.08 & 8.09 & 8.2 & $5.5-8.5^{*}$ \\
\hline L3 & 7.72 & 7.57 & 7.57 & \\
\hline L4 & 7.12 & 7.13 & 6.96 & \\
\hline
\end{tabular}

*Source: MSW Management and Handling Rules, 2000, Compost - Consulting development, 2004 and Soil quality standard from England. 


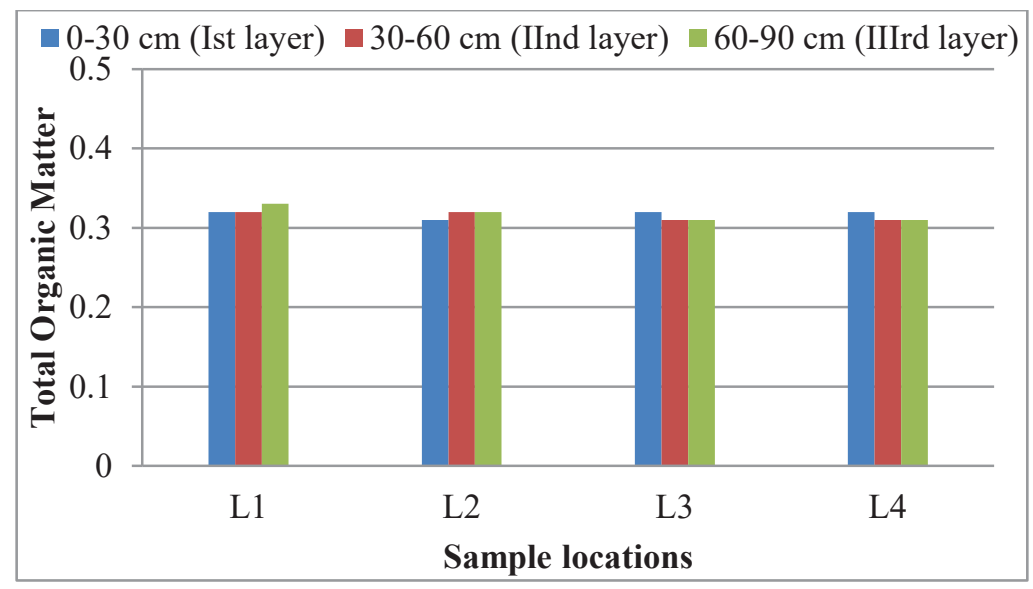

Fig. 6: Variations of total organic matter of the collected soil samples.

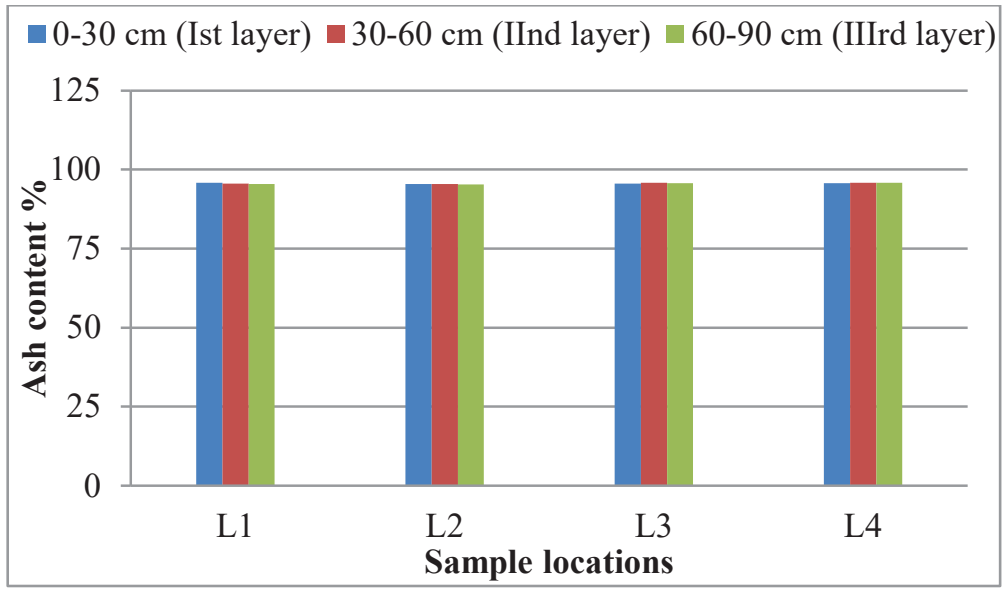

Fig. 7: Variations of ash content of the collected soil samples.

content is expressed as a percentage of the mass of the ovendried sample.

Fig. 7 and Table 5 show the variation in ash content at all the site locations and for each layer. The total organic matter at the $1^{\text {st }}$ layer of the $\mathrm{L} 1$ is higher than that at other site locations. From Fig. 7 , ash content in $1^{\text {st }}, 2^{\text {nd }}$ and $3^{\text {rd }}$ layers at L1 is higher than L2. The level of ash content increases for L3 and then increases for L4 but $2^{\text {nd }}$ layer L4 value decreases.

\section{Total Organic Carbon}

The organic carbon content of a soil is the net result of the rates of carbon input (the rate of net photosynthesis) and organic decay (Isirimah \& Dickson 2008). And it contributes significantly to acidity through contributions from organic acids and biological activities (Yun 2003). Flooded soils, due to their low mineralization rate under reduced conditions tend to accumulate fairly substantial organic carbon contents and

Table 3: Moisture content at various depths in the soil.

\begin{tabular}{|lllll|}
\hline Soil Sample Location & $\begin{array}{l}\text { Ist layer } \\
0-30 \mathrm{~cm}(\%)\end{array}$ & $\begin{array}{l}\text { Ind layer } \\
30-60 \mathrm{~cm}(\%)\end{array}$ & $\begin{array}{l}\text { IIIrd layer } \\
60-90 \mathrm{~cm}(\%)\end{array}$ & $\begin{array}{l}\text { Maximum Allowable Concentra- } \\
\text { tion }(\%)\end{array}$ \\
\hline L1 & 1.18 & 1.51 & 1.45 & 1.52 \\
L2 & 1.52 & 1.47 & 1.23 & $11-17$ \\
L3 & 1.23 & 1.19 & 1.25 & \\
L4 & 1.21 & 1.24 & \\
\hline
\end{tabular}


Table 4: Concentration of total organic matters at various depths in the soil.

\begin{tabular}{|llll|}
\hline $\begin{array}{l}\text { Soil Sample } \\
\text { Location }\end{array}$ & $\begin{array}{l}\text { Ist layer } \\
0-30 \mathrm{~cm}(\%)\end{array}$ & $\begin{array}{l}\text { Ind layer } \\
30-60 \mathrm{~cm}(\%)\end{array}$ & $\begin{array}{l}\text { IIIrd layer } \\
60-90 \mathrm{~cm}(\%)\end{array}$ \\
\hline L1 & 0.32 & 0.32 & 0.33 \\
L2 & 0.31 & 0.32 & 0.33 \\
L3 & 0.32 & 0.31 & 0.31 \\
L4 & 0.31 & 0.32 & 0.31 \\
\hline
\end{tabular}

these have some influence on soil structural behaviour (Toboada 2004). The total organic carbon content is suggestive of microbial activity leading to the release of organic carbon and acidic substances (Morgan et al. 1989).

Fig. 8 and Table 6 clearly show the variation in total organic carbon at all the site locations and for each layer. The total organic carbon at L1 and L2 is higher than the other site locations. The value of total organic carbon is in the range of 0.18 to 0.19 for all the layers of the collected soil samples (Table 8).

\section{Specific Gravity}

Specific gravity $(\mathrm{G})$ is defined as the ratio of mass per volume or ratio of the weight of an equal volume of distilled water at
Table 5: Variation of ash content at various depths in the soil.

\begin{tabular}{|llll|}
\hline $\begin{array}{l}\text { Soil Sample } \\
\text { Location }\end{array}$ & $\begin{array}{l}\text { Ist layer } \\
0-30 \mathrm{~cm}(\%)\end{array}$ & $\begin{array}{l}\text { IInd layer } \\
30-60 \mathrm{~cm}(\%)\end{array}$ & $\begin{array}{l}\text { IIIrd layer } \\
60-90 \mathrm{~cm}(\%)\end{array}$ \\
\hline L1 & 95.78 & 95.53 & 95.49 \\
L2 & 95.44 & 95.39 & 95.37 \\
L3 & 95.61 & 95.8 & 95.75 \\
L4 & 95.71 & 95.77 & 95.79 \\
\hline
\end{tabular}

that temperature; both weights are taken in air. The knowledge of specific gravity is needed in the calculation of soil properties like void ratio; the degree of saturation, etc. Soil specific gravity varies with the depth of the ground whereby we can know the conditions of soil structures below the crust.

Fig. 9 and Table 7 show the variation in specific gravity at all the site locations and for each layer. The specific gravity at L2 is higher than other site locations. From Fig. 9, the value of specific gravity at L1 is lower than L2, and then the value of specific gravity is equal for L 3 and L4 and for $3^{\text {rd }}$ layer L4 value decreases.

\section{Conductivity}

Electrical conductivity is also a very important property of

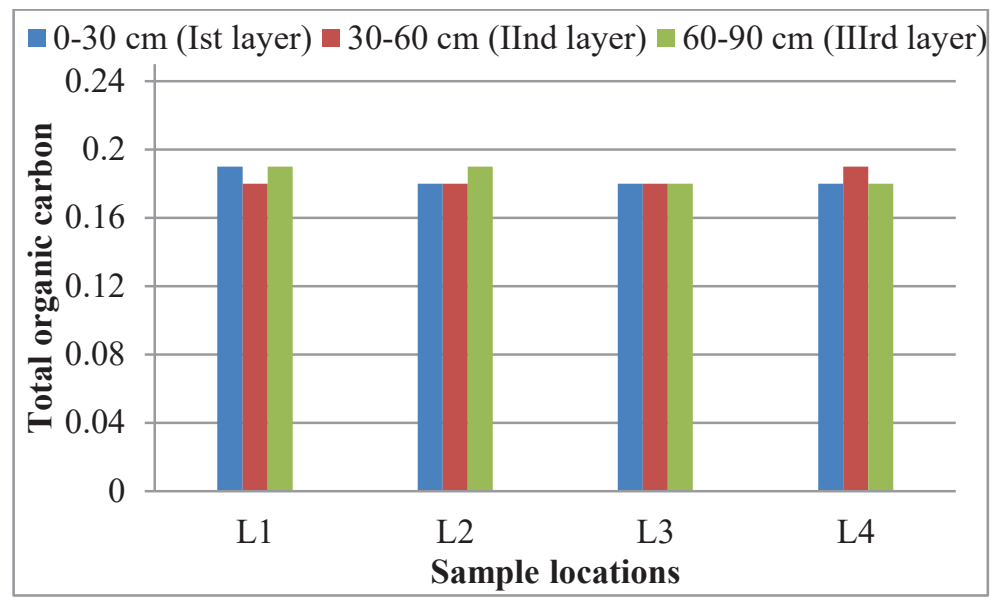

Fig. 8: Variations of total organic carbon of collected soil samples.

Table 6: Total organic carbon at various depths in the soil.

\begin{tabular}{|llll|}
\hline Soil Sample Location & Ist layer 0-30 cm $(\%)$ & Ind layer 30-60 cm $(\%)$ & IIIrd layer 60-90 cm (\%) \\
\hline L1 & 0.19 & 0.18 & 0.19 \\
L2 & 0.18 & 0.18 & 0.19 \\
L3 & 0.18 & 0.18 & 0.18 \\
L4 & 0.18 & 0.19 & 0.18 \\
\hline
\end{tabular}


the soil, which is used to check the quality of the soil. It is a measure of ions present in the solution (Tale \& Ingole 2015). When the soil is more acidic, it shows very high electric conductivity value (Chik 2011). The electrical conductivity of a soil solution increases with the increased concentration of ions. Electrical conductivity is a very quick, simple and inexpensive method to check the health of soils. It is a measure of ions present in the solution. The electrical conductivity of a soil solution increases with the increased concentration of salts.

Fig. 10 and Table 8 show the variation in conductivity at all the site locations for each layer. The conductivity at L2 is higher than other site locations. From the Fig.10, the value of conductivity at $\mathrm{L} 1$ is lower than $\mathrm{L} 2$, and the value of conductivity decreases for L3 and L4.
If the soil EC is too high, it can be an indication of a high level of exchangeable sodium. Soils with an accumulation of exchangeable sodium are often characterized as low permeability. The soil EC is also related to the specific soil properties that affect the $\mathrm{pH}$, salt concentrations and water holding capacity. It is difficult to say the ideal EC levels, as there are so many variables affecting the EC level.

\section{Bulk Density}

Bulk density is defined as the mass of many particles of the material divided by the total volume they occupy. Bulk density is a property of powders, granules, and other masses of particulate matter. Bulk density can change depending on how the material is handled. Bulk density of soil samples is within the Indian standards. It is noted that the bulk density

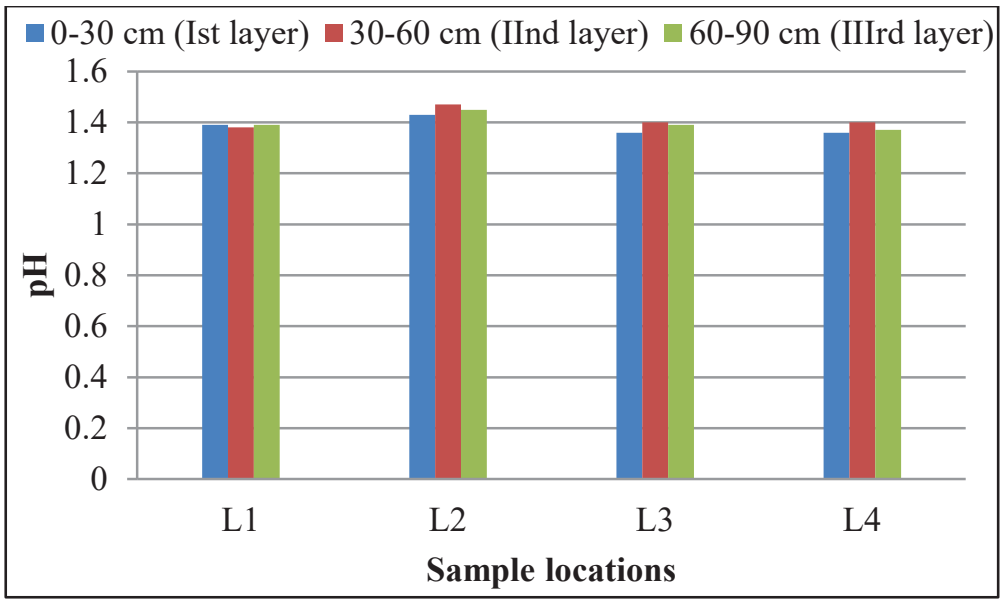

Fig. 9: Variations of specific gravity of the collected soil samples.

Table 7: Specific gravity at various depths in the soil.

\begin{tabular}{|llll|}
\hline Soil Sample Location & Ist layer 0-30 cm & IInd layer 30-60 cm & IIIrd layer 60-90 cm \\
\hline L1 & 1.39 & 1.38 & 1.39 \\
L2 & 1.43 & 1.47 & 1.45 \\
L3 & 1.36 & 1.4 & 1.39 \\
L4 & 1.36 & 1.4 & 1.37 \\
\hline
\end{tabular}

Table 8: Conductivity at various depths in the soil.

\begin{tabular}{|lllll|}
\hline $\begin{array}{l}\text { Soil Sample } \\
\text { Location }\end{array}$ & $\begin{array}{l}\text { Ist layer-0-30 cm } \\
(\mu \mathrm{S} / \mathrm{cm})\end{array}$ & $\begin{array}{l}\text { Ind layer-30-60 cm } \\
(\mu \mathrm{S} / \mathrm{cm})\end{array}$ & $\begin{array}{l}\text { IIIrd layer-60-90 cm } \\
(\mu \mathrm{S} / \mathrm{cm})\end{array}$ & $\begin{array}{l}\text { Maximum Allowable Concentration } \\
(\mu \mathrm{S} / \mathrm{cm})\end{array}$ \\
\hline L1 & 304 & 256 & 219 & \\
L2 & 323 & 274 & 336 & $200 \mu \mathrm{S} / \mathrm{cm}$ and $1200 \mu \mathrm{S} / \mathrm{cm}(\mathrm{General}$ \\
L3 & 255 & 192 & 211 & guidelines for good soil $)$ \\
L4 & 148 & 155 & 200 & \\
\hline
\end{tabular}




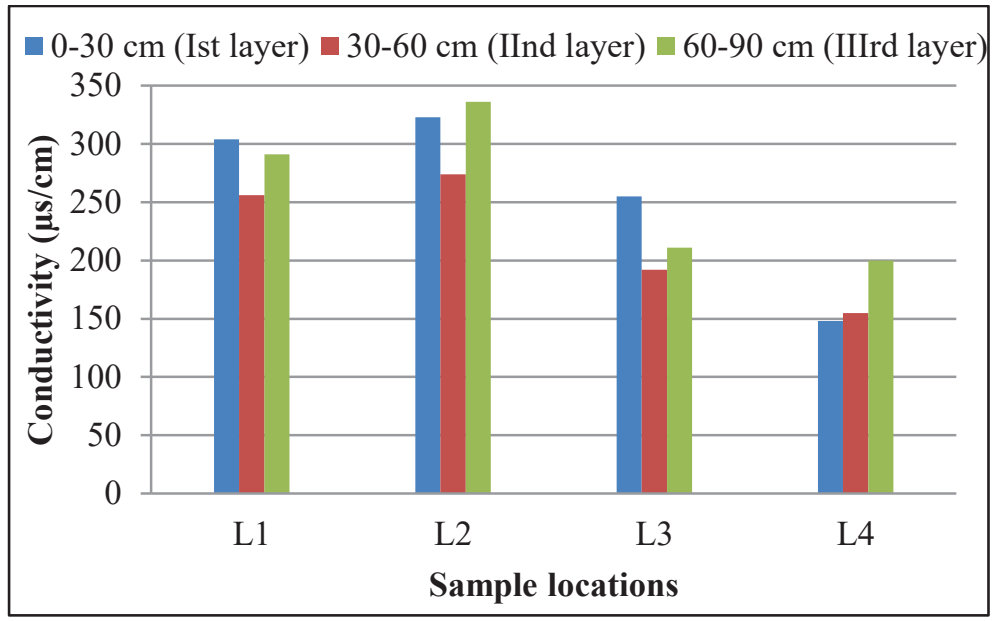

Fig. 10: Variations of conductivity of the collected soil samples.

Table 9: Bulk density at various depths in the soil.

\begin{tabular}{|lllll|}
\hline $\begin{array}{l}\text { Soil Sample } \\
\text { Location }\end{array}$ & $\begin{array}{l}\text { Ist layer-0-30 cm } \\
\left(\mathrm{g} / \mathrm{cm}^{3}\right)\end{array}$ & $\begin{array}{l}\text { IInd layer-30-60 } \mathrm{cm} \\
\left(\mathrm{g} / \mathrm{cm}^{3}\right)\end{array}$ & $\begin{array}{l}\text { IIIrd layer-60-90 cm } \\
\left(\mathrm{g} / \mathrm{cm}^{3}\right)\end{array}$ & $\begin{array}{l}\text { Maximum Allowable Concentration } \\
\left(\mathrm{g} / \mathrm{cm}^{3}\right)\end{array}$ \\
\hline L1 & 1.53 & 1.39 & 1.34 & $1-1.6$ \\
L2 & 1.6 & 1.46 & 1.35 & 1.36 \\
L3 & 1.46 & 1.42 & 1.43 \\
L4 & 1.52 & 1.41 & \\
\hline
\end{tabular}

of soil sample collected from L 2 of the $\mathrm{I}^{\text {st }}$ layer is the highest among all the collected soil samples, which is $1.6\left(\mathrm{~g} / \mathrm{cm}^{3}\right)$.

Fig. 11 and Table 9 show the variation in bulk density at all the site locations for each layer. The bulk density at L2 of the $1^{\text {st }}$ layer is higher than other site locations. From the Fig.11, the value of bulk density at L1 is lower than L2, the value of bulk density decreases for L3 ( $1^{\text {st }}$ and $2^{\text {nd }}$ layer $)$ and increases for L3 of the $3^{\text {rd }}$ layer and L4 of the $1^{\text {st }}$ layer and $3^{\text {rd }}$ layer increases and then decreases for L 4 of the $2^{\text {nd }}$ layer.

\section{CONCLUSION}

The $\mathrm{pH}$ of the study area, i.e., near the dumpsite within 1.5

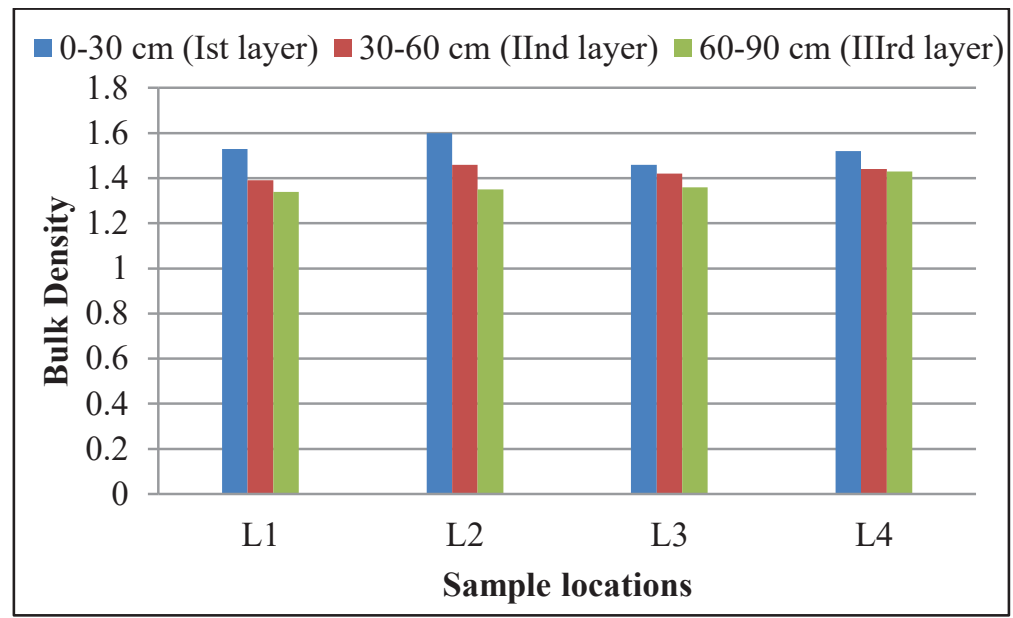

Fig. 11: Variations of bulk density of collected soil samples. 
$\mathrm{km}$ varies from 7.84 to 8.2 , and away from the dumpsite, i.e. beyond $1.5 \mathrm{~km}$, varies from 6.9 to 7.72 , the values are below the standard value specified by the MoEF. It indicates that the $\mathrm{pH}$ of the soil varies from slightly neutral to highly alkaline. The percentage of moisture content in the soil samples varies from $1.18 \%$ to $1.52 \%$ and $1.19 \%$ to $1.25 \%$ near and away from the dumpsite respectively, which are below the standard value range of 11 to $17 \%$. EC level of the sampling locations ranges from $219 \mu \mathrm{S} / \mathrm{cm}$ to $336 \mu \mathrm{S} / \mathrm{cm}$ and $148 \mu \mathrm{S} / \mathrm{cm}$ to 255 $\mu \mathrm{S} / \mathrm{cm}$ near and away from the dumpsite respectively, which are between $200 \mu \mathrm{S} / \mathrm{cm}$ and $1200 \mu \mathrm{S} / \mathrm{cm}$ (general guideline level). Soils having EC levels below $200 \mu \mathrm{S} / \mathrm{cm}$ are sterile soil with little microbial activity. And EC above $1200 \mu \mathrm{S} /$ $\mathrm{cm}$ may indicate a salinity problem due to lack of drainage. The bulk density of the soil samples varies from $1.34 \mathrm{~g} / \mathrm{cm}^{3}$ to $1.60 \mathrm{~g} / \mathrm{cm}^{3}$ and $1.36 \mathrm{~g} / \mathrm{cm}^{3}$ to $1.52 \mathrm{~g} / \mathrm{cm}^{3}$ at near and away from the dumpsite respectively, which are with the standard value range of $1.0 \mathrm{~g} / \mathrm{cm}^{3}$ to $1.6 \mathrm{~g} / \mathrm{cm}^{3}$. The TOC of the soil samples varies from $0.18 \%$ to $0.19 \%$ both near and away from the dumpsite which is with the value range of $0.1 \%$ to $0.62 \%$. As the organic content is low it allows the contaminant from the solid waste to enter the groundwater. If the organic matter content of the subsoil is high it prevents the pollutants from reaching the groundwater sources as it plays an important role in the adsorption in the soil.

Therefore proper solid waste management practice should be implemented to minimize the adverse impact on the soil. Further in situ bioaccumulation studies can also be performed to avoid soil contamination due to open dumping of solid waste. Since the study area is near the non engineered recently closed dumpsite/landfill implementing the new technology providing permeable reactive barriers (PRBs) using low-cost materials available locally will enhance the prevention of soil pollution, otherwise, these pollutants constantly migrate and permeate into soil strata and after a certain period, the entire groundwater system is polluted.

\section{REFERENCES}

Chik, Z. 2011. Study of chemical effects on soil compaction characterizations through electrical conductivity. Int. J. Electrochemical. Sci., 6: 6733-6740.

Deshmukh, K.K. 2012. Studies on chemical characteristics and classification of soils from Sangamner area, Ahmednagar District, Maharashtra, India. Rasayan Journal of Chemistry, 5(1): 74-85.

Igwe, C., Isirimah, N. O. and Teme, S. C. 2002. Distribution and characteristics of solid wastes and waste disposal sites in Port Harcourt municipality, Rivers State, Nigeria. African Journal of Environmental Pollution and Health, 1(2): 51-60.

Isirimah, N. O. and Dickson, A. 2003. Soil chemistry. In: Introductory Soil Chemistry and Biology for Agriculture and Biotechnology. OSIA International Publishers Ltd., Port Harcourt.

Isirimah, N. O. and Yun, O. 2003. Simulating dynamic load of naturally occurring total organic carbon (TOC) from watershed. Water Research, 37: 823-832.

Morgan, P. and Watkinson, R.J. 1989. Hydrocarbon degradation in soils and methods for soil biotreatment. CRC Critical Reviews. Biolechnol, 8(4): 305-330.

Oguche, J.A. 2013. Spatial location of solid waste dumpsites and collection scheduling using the geographic information systems in Bauchi Metropolis Nigeria. European Scientific Journal, 9(11): 374-382.

Oguneleka, T. C. H. 2009. Municipal solid waste characteristics and management in Nigeria. Iranian Journal of Environmental Health Science and Engineering, 6(3): 173-180.

Praveena, S. G. and Rao, P.V. 2016. Impact of leachate on soil properties in the dumpsite. International Journal of Engineering Research and General Science, 4(11): 235-241.

Schoenholtz, S. H. 2000. A review of chemical and physical properties as indicators of forest soil quality: Challenges and opportunities. Forest Ecology and Management, 138: 335-356.

Sharma, R. K., Agrawal, M. and Marshall, F. 2007. Heavy metal contamination of soil and vegetables in suburban areas of Varanasi, India. Ecotoxicol Environ. Safety, 66(2): 258-266.

Tale, Smita and Ingole, Sangita 2015. A review on role of physico-chemical properties in soil quality, Chem. Sci. Rev. Lett., 4(13): 57-66.

Toboada, M.A. 2004. Soil Structural Behaviour of Flooded Soils. No. INIS-XA-989. 2004.

Uma, R. N., Prem Sudha, R. and Murali, K. 2016. Analysis of physico-chemical characteristics of soil and SQI around municipal solid waste dump yard in Vellalore-Coimbatore, Tamilnadu. India. Int. J. Chem. Sci., 14(4): 3265-3276. 